Proceedings of the XXIII Conference on Applied Crystallography, Krynica Zdrój, Poland, September 20-24, 2015

\title{
Zinc Oxide/Cuprous(I) Oxide-Based Solar Cells Prepared by Electrodeposition
}

\author{
M. PŁaWECKi*, E. RóWiński, Ł. Mieszczak \\ Institute of Materials Science, University of Silesia, 75 Pułku Piechoty 1A, 41-500 Chorzów, Poland \\ The aim of this research was to fabricate zinc oxide/cuprous(I) oxide-based heterojunction solar cells with \\ the use of electrodeposition methods, and further to investigate their structures and photovoltaic properties. The \\ $\mathrm{ZnO}$ and $\mathrm{Cu}_{2} \mathrm{O}$ were used as $n$ - and $p$-type semiconductors, respectively, to fabricate photovoltaic devices based \\ on $\mathrm{Ag} / \mathrm{ZnO} / \mathrm{Cu}_{2} \mathrm{O} / \mathrm{Cu}(100)$ heterojunction structures. The crystallite sizes of $\mathrm{ZnO}$ and $\mathrm{Cu}_{2} \mathrm{O}$ were determined to \\ be $25.4(3) \mathrm{nm}$ and $69.8(6) \mathrm{nm}$, respectively. It was pointed out that efficiencies of the solar cells can be gradually \\ adjusted, using different thicknesses of $\mathrm{Cu}_{2} \mathrm{O}$ layers, to achieve values as high as $2.7 \%$. The standard diode \\ model and high device performance provide new insights into the issue, outlining guidelines for high-performance \\ solar cells and suggesting that a metal- $n$-type semiconductor- $p$-type semiconductor nanostructure-crystal layered, \\ sandwiched-type architecture is a promising platform to boost the efficiency.
}

DOI: $10.12693 /$ APhysPolA.130.1144

PACS/topics: 61.05.cp, 73.50.Pz, 73.40.Sx

\section{Introduction}

The solar cells based on copper oxide and zinc oxide are a promising alternative to conventional silicon cells because of the relatively low cost of production and theoretical efficiency of $\approx 16 \%$ [1-9]. This paper focuses on the characteristics of the $\mathrm{ZnO}$ layer $-n$-type, and $\mathrm{Cu}_{2} \mathrm{O} / \mathrm{CuO}-p$-type semiconductors prepared by using a method of electrodeposition, which allows to create transparent semiconductor layers with good optoelectronic properties [4]. Cuprous(I) oxide $\left(\mathrm{Cu}_{2} \mathrm{O}\right)$ semiconductors are promising elements of a whole functionaloxide solar cell material because of their photoelectronic properties - band-gap energy of $2.1 \mathrm{eV}$, environmental friendly properties such as non-toxicity and low material cost $[1,2]$.

One of the primary motivations of this research is the change of solar cell architecture. In other words, one can change the device architecture to the inverted structure in which a hole-blocking layer (such a zinc oxide, $\mathrm{ZnO}$ ) is inserted between a silver electrode and an active layer of $\mathrm{Cu}_{2} \mathrm{O}$. It was proven that an optimization of thickness of $\mathrm{Cu}_{2} \mathrm{O}$ layer could increase the efficiency of $\mathrm{ZnO} / \mathrm{Cu}_{2} \mathrm{O}$ based heterojunction solar cells. In order to improve efficiency, dependence between structural medication and photovoltaic properties were investigated.

\section{Materials and methods}

The $\mathrm{Cu}_{2} \mathrm{O}$ and $\mathrm{ZnO}$ layers were deposited layer-bylayer one on crystalline $\mathrm{Cu}(100)$ base with a $5 \mathrm{~mm}$ thickness by applying a method of electrodeposition. Platinum wire was used as a counter electrode in each process.

The $\mathrm{Cu}_{2} \mathrm{O}$ layer was obtained from electrolyte-solution of copper(II) sulfate $\left(\mathrm{CuSO}_{4}, 0.4 \mathrm{~mol} / \mathrm{L}\right.$, Wako $\left.97.5 \%\right)$,

*corresponding author; e-mail: mplawecki@us.edu.pl
L-lactic acid (3 mol/L, Wako) and distilled water. The electrolyte $\mathrm{pH}$ was adjusted to 12.5 by adding $\mathrm{NaOH}$. During the deposition the solution temperature was kept at $65{ }^{\circ} \mathrm{C}$ and the current density at $1.5 \mathrm{~mA} / \mathrm{cm}^{2}$. The process time was set to: $20,40,60,80$, and $100 \mathrm{~min}$. The estimated thicknesses of the $\mathrm{Cu}_{2} \mathrm{O}$ layers were calculated from the value of current density, deposition time and the Faraday law and confirmed by cross-section SEM investigation. The obtained values were: $1,2,3,4$, and $5 \mu \mathrm{m}$, respectively, for each deposition time.

The $\mathrm{ZnO}$ layers were galvanostatically electrodeposited from $0.025 \mathrm{M}$ aqueous solution of $\mathrm{Zn}\left(\mathrm{NO}_{3}\right)$ at the temperature of $75^{\circ} \mathrm{C}$ on the $\mathrm{Cu}_{2} \mathrm{O}$ substrates. The current density of electrodeposition was set at $3 \mathrm{~mA} / \mathrm{cm}^{2}$ and the electrodeposition time was set to $50 \mathrm{~min}$. The thickness of the $\mathrm{ZnO}$ layers was determined to be $250 \mathrm{~nm}$. Because of the constant deposition time, the thickness of the $\mathrm{ZnO}$ layer was unmodifiable in all samples. The top electrodes of silver paste (TAAB, S 270) were printed on the rear of $\mathrm{ZnO}$. The $\mathrm{ZnO} / \mathrm{Cu}_{2} \mathrm{O}$ solar cells prepared in the present study were investigated by a structural analysis, spectroscopic and photovoltaic measurements.

All the crystalline components in the $\mathrm{Ag} / \mathrm{ZnO} / \mathrm{Cu}_{2} \mathrm{O} / \mathrm{Cu}(100)$ solar cells were investigated by $\mathrm{X}$-ray diffraction (XRD) and grazing incidence X-ray diffraction (GIXD) on an Empyrean PANalytical powder diffractometer, using $\mathrm{Cu} K_{\alpha}$ radiation.

The spectroscopic studies were carried out in the vacuum system with the use of PHI 660/5700 spectrometer. All the measurements were taken at room temperature.

The current-voltage characteristics were carried out by 2400 Series Source Meter, Keithley Instruments. The source of the simulated light was a $75 \mathrm{~W} 4000 \mathrm{~K}$ xenon lamp equipped with a sunlight filter to adjust the emission spectrum of the lamp to the $1000 \mathrm{~W} / \mathrm{m}^{2}$. The solar cells were covered with a metal aperture to define an active area of $0.01 \mathrm{~cm}^{2}$. 


\section{Results and discussion}

First, the structure of the deposited layers were investigated. For this purpose the layers were deposited separately on cuprous substrates. Only after structural investigation samples were fabricated as functional devices to study optoelectronic properties. XPS measurements were performed on $\mathrm{Cu}(100)$ substrate in order to reveal possible contaminations and to determine $\mathrm{Cu}$ baseline positions for further references. The examination of the spectra did not reveal the existence of contaminations.

Figure 1a shows the GI XRD patterns obtained at $1^{\circ}$, $2^{\circ}, 3^{\circ}$, and $5^{\circ}$ incidence angles of $\mathrm{Ag} / \mathrm{ZnO}$ interfaces. Based on this results the conclusions are that there are not any processes such as diffusion, atoms exchange, or oxidation between $\mathrm{Ag} / \mathrm{ZnO}$ and $\mathrm{ZnO} / \mathrm{Cu}_{2} \mathrm{O}$ layers. It was found that $\mathrm{Cu}_{2} \mathrm{O}$ layers are polycrystalline with no traces of $\mathrm{CuO}$ (Fig. 1b). The XRD patterns for $\mathrm{Cu}_{2} \mathrm{O}$ were obtained from PDF2 00-001-1142 card. The crystallite size was estimated using the well-known Scherrer equation. The crystallite sizes of $\mathrm{Ag}, \mathrm{ZnO}$, and $\mathrm{Cu}_{2} \mathrm{O}$ were determined to be 5.8(2), 25.4(3), and 69.8(6) nm, respectively. Figure 1c shows the backscatter Laue diffraction pattern from the front (100) face of the crystalline copper. The Laue diffraction pattern is very symmetric, with sets of diffraction spots arranged in the rings around the centre of the pattern. The core-level XPS spectrum for $\mathrm{Cu} 2 p$ spectral lines measured from a surface of $\mathrm{Cu}(100)$ is shown in Fig. 1d. This spectrum consists of $\mathrm{Cu} 2 p_{3 / 2}$ and $\mathrm{Cu} 2 p_{1 / 2}$ lines. The first unshifted part of the main lines refers to copper. The second shifted part depicts the $\mathrm{Cu}^{+}$ion of $\mathrm{CuO}$ bonds [10]. The $\mathrm{O}^{2-}$ ions are either from the $\mathrm{Cu}_{2} \mathrm{O}$ interlayer or from oxidation of the metallic $\mathrm{Cu}$ due to the exposure to air in spite of the surface preparing methods.

In order to optimize the cell efficiency and its thickness it is necessary to determine the best thickness value of $\mathrm{Cu}_{2} \mathrm{O}$ layer. For this purpose the optoelectronic properties - the current-voltage characteristics were carried out. The basic current mechanism could be described by diode equation. The diode equation shown in (1) describe the current-voltage characteristic of a solar cell under illumination and can be written as [7, 8]:

$$
I(U)=I_{0}^{\mathrm{eff}}\left[\exp \left(\frac{q U}{k_{\mathrm{B}} T n^{\mathrm{eff}}}\right)-1\right]-I_{s c},
$$

where $I(U)$ - the total current, $U$ - voltage, $I_{s c}$ - the short circuit current (photogenerated current), $I_{0}^{\text {eff }}$ - the effective saturation current, $q$ - the elementary charge, $k_{\mathrm{B}}$ - the Boltzmann constant, $T$ - the absolute temperature, $n^{\text {eff }}$ - the effective ideality factor. In this equation the influence of ohmic and recombination currents is included in $I_{0}^{\text {eff }}$ and $n^{\text {eff }}$ parameters.

Figure 2 presents the results from current-voltage characteristic tests (a)-(e) and calculations of power obtained from this experimental data (f)-(j). The shape (tendency) of $U-I$ and $U-P$ curves is unchanged despite the change of $\mathrm{Cu}_{2} \mathrm{O}$ layer thickness. The shapes of $U-I$ are exponential and the $U-P$ upset down parabolic-like.
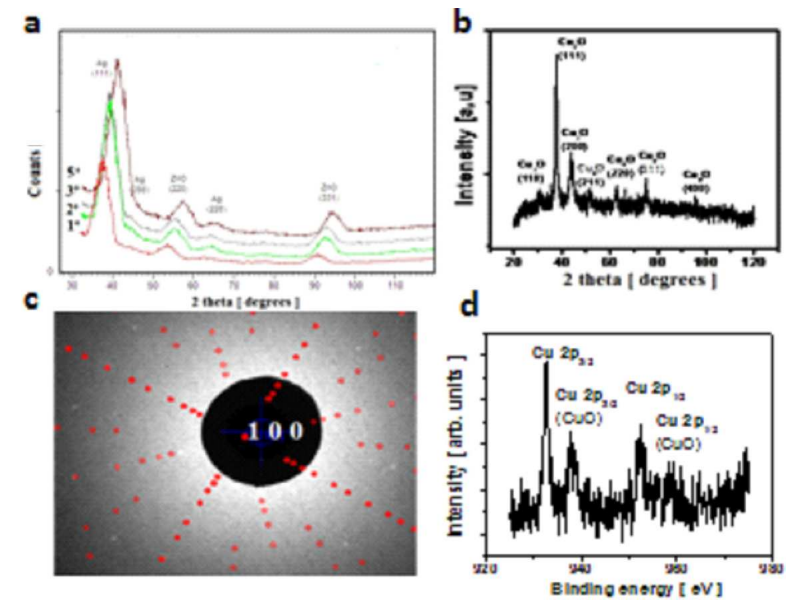

Fig. 1. (a) GI XRD at $1^{\circ}, 2^{\circ}, 3^{\circ}$, and $5^{\circ}$ incidence angles of $\mathrm{Ag} / \mathrm{ZnO}$ interface. (b) GI XRD at $1^{\circ}$ incidence angle of $\mathrm{Cu}_{2} \mathrm{O}$ layer. (c) Backscatter Laue diffraction pattern from the crystalline (100) copper substrates. (d) The XPS core level spectrum of $\mathrm{Cu} 2 p$ registered from $\mathrm{Cu}(100)$ substrate for increase of the etching time of $60 \mathrm{~s}$ using the beam of $\mathrm{Ar}^{+}$ions of $500 \mathrm{eV}$ energy.

a

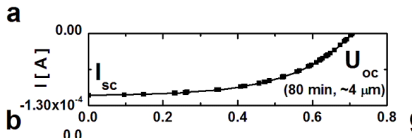

f
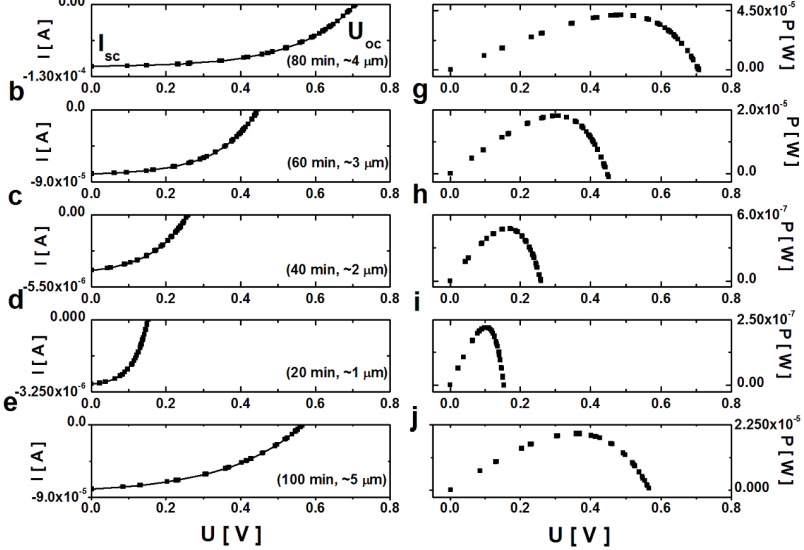

Fig. 2. Experimental (dots) and theoretical (solid lines) current-voltage characteristics of the $\mathrm{Ag} /$ $\mathrm{ZnO} / \mathrm{Cu}_{2} \mathrm{O} / \mathrm{Cu}(100)$ solar cells as a function of electrodeposition times $(\mathrm{a}, \mathrm{b}, \mathrm{c}, \mathrm{d}, \mathrm{e})$ and their power-voltage curves (f,g,h,i,j). (a)-(e) Current-voltage characteristics of $\mathrm{Ag} / \mathrm{ZnO} / \mathrm{Cu}_{2} \mathrm{O} / \mathrm{Cu}(100)$ and $(\mathrm{f})-(\mathrm{j})$ powervoltage curve of $\mathrm{Ag} / \mathrm{ZnO} / \mathrm{Cu} 2 \mathrm{O} / \mathrm{Cu}(100)$ of $\mathrm{Cu}_{2} \mathrm{O}$ thickness $4,3,2,1$, and $5 \mu \mathrm{m}$, respectively.

The influence of the $\mathrm{Cu}_{2} \mathrm{O}$ interlayer thickness $d$ is shown in form of shifts of the open-circuit voltage $\left(U_{o c}\right)$ and $P$ peaks in direction of larger values of $U$ (see Fig. 2 and Table I). The values of solar cell parameters are also presented in Table I. It is very important to predict these characteristics to obtain maximum possible power.

The analysis of the data given in Table I shows that the values of electrical parameters depend on the thickness of $\mathrm{Cu}_{2} \mathrm{O}$ layer. The efficiency of the solar cells varies between $0.04 \%$ and $1.71 \%$. The maximum value was 
TABLE I

The measured parameters of the present solar cells. aa thickness of $\mathrm{Cu}_{2} \mathrm{O}$ layer of $\mathrm{Ag} / \mathrm{ZnO} / \mathrm{Cu}_{2} \mathrm{O} / \mathrm{Cu}(100)$ solar cells $[\mu \mathrm{m}], \mathrm{bb}$ - open-circuit voltage $U_{o c}[\mathrm{~V}]$, cc - shortcircuit current density $J_{s c}\left[\mathrm{~A} / \mathrm{m}^{2}\right]$, dd - fill factor $F F$, ee - efficiency $\eta[\%]$

\begin{tabular}{c|c|c|c|c}
\hline \hline aa & bb & cc & dd & ee \\
\hline 1 & 0.15 & 5.8 & 0.44 & 0.04 \\
2 & 0.26 & 13.2 & 0.47 & 0.16 \\
3 & 0.45 & 46.5 & 0.41 & 0.86 \\
4 & 0.71 & 92.6 & 0.42 & 1.71 \\
5 & 0.57 & 88.0 & 0.32 & 1.6
\end{tabular}

a
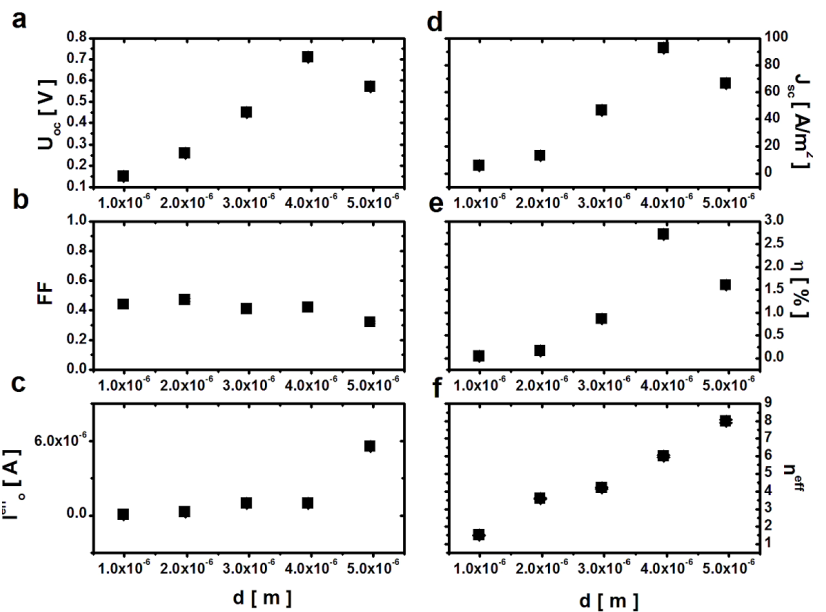

Fig. 3. The solar-cell parameters as a function of $\mathrm{Cu}_{2} \mathrm{O}$ layer thickness $d$ for $\mathrm{Ag} / \mathrm{ZnO} / \mathrm{Cu}_{2} \mathrm{O}$. (a) The opencircuit voltage $U_{o c}$. (b) The fill factor $F F$. (c) The effective saturation current $I_{0}^{\text {eff }}$. (d) The density of short circuit current $J_{s c}$. (e) The efficiency $\eta$. (f) The effective ideality factor $n^{\text {eff }}$.

obtained at thickness of $4 \mu \mathrm{m}$. Relative errors were smaller than $3 \%$.

Figure 3a shows the fitted data based on Eq. (1). The results are in a good agreement with the experimental records. The mismatch between the analysis and the data from the current-voltage characteristics leads to different values of the effective solar parameters (Fig. 3b). On the basis of this model we were able to adjust the experimental data and get values of effective parameters (see Fig. 3c-f). Figure 3e and $\mathrm{f}$ shows the values of $I_{0}^{\text {eff }}$ and $n^{\text {eff }}$ obtained with Eq. (1). The results show behavior of the $n^{\text {eff }}$ values in the range from 1.5 to 8 . These values are approximately 3 times higher than obtained from tests.

\section{Conclusions}

It was shown that for a typical $\mathrm{Ag} / \mathrm{ZnO} / \mathrm{Cu}_{2} \mathrm{O} / \mathrm{CuO} / \mathrm{Cu}(100)$-based heterojunction solar cell with a $250 \mathrm{~nm}$ thick $\mathrm{ZnO}$ interlayer the optimal thickness value of $\mathrm{Cu}_{2} \mathrm{O}$ interlayer is about $4 \mu \mathrm{m}$. The efficiency of such solar cells was found to be $1.71 \%$. The results obtained from the diode model used in this study is in a good agreement with the experimental current-voltage data. The model allows to determine the values of the $I_{0}^{\text {eff }}$ and $n^{\text {eff }}$ parameters. All of the investigated values of solar cell parameters strongly depend on the thickness of $\mathrm{Cu}_{2} \mathrm{O}$ interlayer.

\section{References}

[1] K. Fujimoto, T. Oku, T. Akiyama, A. Suzuki, J. Phys. Conf. Series 433, 012024 (2013).

[2] S. Noda, H. Shima, H. Akinaga, J. Phys. Conf. Series 433, 012027 (2013).

[3] V. Popescu, G. Bester, M.C. Hanna, A.G. Norman, A. Zunger, Phys. Rev. B 78, 205321 (2008).

[4] O. Breitenstein, Opto-Electron. Rev. 21, 259 (2013).

[5] A. Boudghene-Stambouli, E. Traversa, Renew. Sustain. En. Rev. 6, 433 (2002).

[6] C. Hung Hsu, L. Chen, Y. Lin, Materials 6, 4479 (2013).

[7] R.T. Tung, Mater. Sci. Eng. R35, 1 (2001).

[8] Y. An, A. Behnam, E. Pop, Appl. Phys. Lett. 102, 013110 (2013).

[9] T. Oku, T. Yamada, K. Fujimoto, T. Akiyama, Coatings 4, 203 (2014).

[10] T. Ghodselahi, M.A. Vesaghi, A. Shafiekhani, A. Baghizadeh, M. Lameii, Appl. Surf. Sci. $\mathbf{2 5 5}$ 2730 (2008). 